Portland State University

PDXScholar

2-18-1976

\title{
A Survey of Small Mammals on Islands in the Columbia and Willamette Rivers
}

Gayle Kirk

Portland State University

Follow this and additional works at: https://pdxscholar.library.pdx.edu/open_access_etds

Part of the Biology Commons

Let us know how access to this document benefits you.

\section{Recommended Citation}

Kirk, Gayle, "A Survey of Small Mammals on Islands in the Columbia and Willamette Rivers" (1976).

Dissertations and Theses. Paper 2362.

https://doi.org/10.15760/etd.2359

This Thesis is brought to you for free and open access. It has been accepted for inclusion in Dissertations and Theses by an authorized administrator of PDXScholar. For more information, please contact pdxscholar@pdx.edu. 
AN ABSTRACT OF THE THESIS OF Gayle Kirk for the Master of Science in Biology presented Fetruary 18, 1976.

Title: A Survey of Small Mammals on Islands in the Columbia and Willamette Rivers

APPROVED BY MEMBERS OF THE THESIS COMMITTEE:
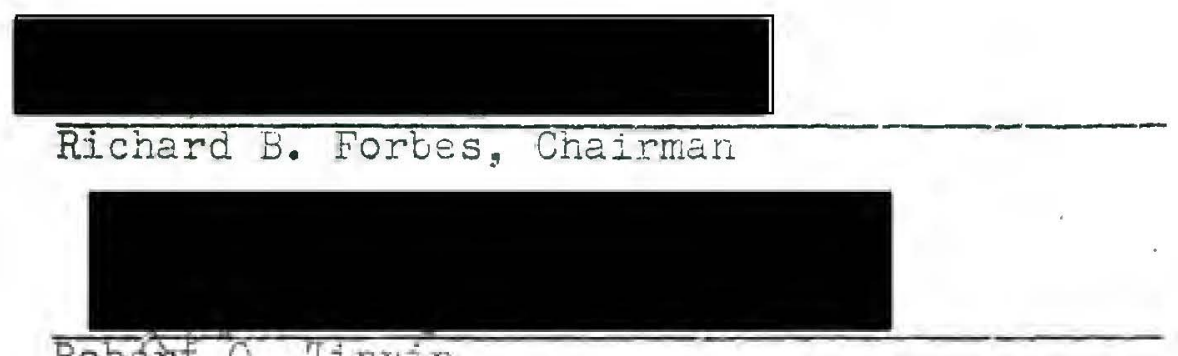
Robert 0. Iinitin

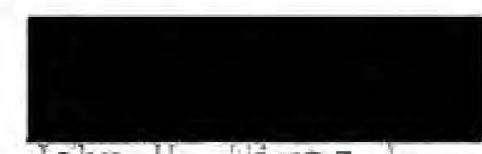

John H. Wirtz

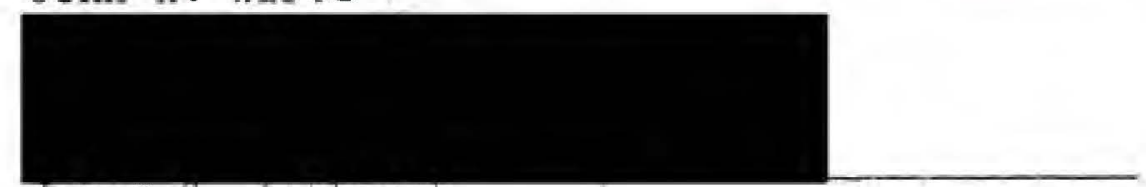
Jame S G. Asnoatigh

A survey of small mammals on eight islands in the Columbia and Willamette Rivers near Portland, Oregon was conducted in 1974. The islands were Government, Sand, Lemon, McGuire and Sandy Islands in the Columbia River and East, Ross and Herdtack Islands in the Willamette River. The objeatives of the study were to ascertain and compare the kinds, distribution and relative densitites of small mammals. 
A variety of traps was used to capture the animals including Museurn Special Rodent Traps, back-break mouse traps, scissor and guillotine-type stáb mole traps, Sherman traps, modified Young traps and pitfalls. Most traps were set in linear transects. Trapping was conducted with the objective of sampling the major habitats on each island. Observations of scats, tracks, burrows and dead animals were also noted.

One species of small mammal, Sorex vagrans, was found on all eight islands. Microtus was found on five islands and Peromyscus maniculatus on four islarids. Two islands yielded Scapanus townsendii. Glaucomvs sabrinus was found on only one island.

I hoped that evidence would be found to prove or disprove that current theories of island biogeography would apply to river islands. However, data in this study were inadequate to allow calculation of precise indices of population densities. Therefore, I was unable to determine if theories of island biogeography do apply to these river islands. 
A SURVEY OF SMAIL MAMMALS ON ISLANDS IN THE COLUMBIA AND WILLAMETTE RIVERS

by

GAYLE KIRK

A thesis submitted in partial fulfillment of the requirements for the degree of

\section{MASTER OF SCIENCE}

in

BIOLOGY

Portland State Iniversity

1976 


\section{ACKNOWLEDGMEN'TS}

I would like to thank my advisor, Dr. R.B. Forbes for his advice during the course of this study. My thanks also go to the members of my thesis committee, Dr. R.O. Tinnin, Dr. J.H. Wirtz and Dr. J.G. Ashbaugh. I am particularly grateful to my husband for his help with the field work as well as his advice and encouragement. 
TABLE OF CONTENTS

PAGE

ACKNOWLEDGMENTS. . . . . . . . . . . .

LIST OF TABLES . . . . . . . . . . . . . V v

LIST OF FIGURES. . . . . . . . . . . . . vi vi

INTRODUCTION . . . . . . . . . . . . I I

MATERIALS AND METHODS. . . . . . . . . . 4

DESCRIPTION OF ISLANDS . . . . . . . . . . 7

I GOVERNMENT ISLAND COMPLEX. . . . . . . 7

II SANDY ISLAND ........... 10

III ROSS ISLAND COMPLEX. ......... 10

RESULTS. . . . . . . . . . . 14

DISCUSSION . . . . . . . . . . . 18

SUMMARY. . . . . . . . . . . . . 26

IITERATURE CITED . . . . . . . . . . . 27 


\section{LIST OF TABLES}

TABLE

PAGE

I Checklist of Mammals. . . . . . .

II Collection Data from Islands in the

Columbia and Willamette Rivers. . .

III Additional Observations of Mammals. . . 


\section{IJIST OF FIGURES}

FIGURE

PAGE

1 Location of the Islands Surveyed . . . . 3

2 Government Island Complex. . . . . . . 8 -

3 Sandy Island . . . . . . . . . . 11

4 Ross Island Complex. . . . . . . . . 12 


\section{INTRODUCTION}

A number of islands are found near the vicinity of the confluence of the Columbia and Willamette Rivers near Portland, Oregon. Located in an urban area, but accessible only by boat, these islands offer a unique opportunity for recreation and nature study. However, their location also makes them targets for potential commercial or industrial development.

A review of the literature failed to reveal any organized information concerning small mammals on these islands. Knowledge of the species present is an essential prerequisite to understanding the biogeography of the islands. Moreover, such information should be used by planners in evaluating possible environmental impacts of different kinds of activity proposed for the isiands. Also, with increasing recreational use of the islands, the probability of transmission of certain diseases such as leptospirosis, from wild mammals to humans and/or their domestic animals increases. Evaluation of possible disease reservoirs on the islands requires knowledge of the small mammals living there.

Accordingly, a survey of small mammals on eight of the islands was undertaken in 1974. The islands studied were Government, Sand, Lemon, McGuire and Sandy Islands in 
the Columbia River, and East, Ross and Hardtack Islands in the Willamette River (Figure 1). The objectives of the study were to ascertain and compare the kinds, distribution and relative population densities of small mammals on the islands. 


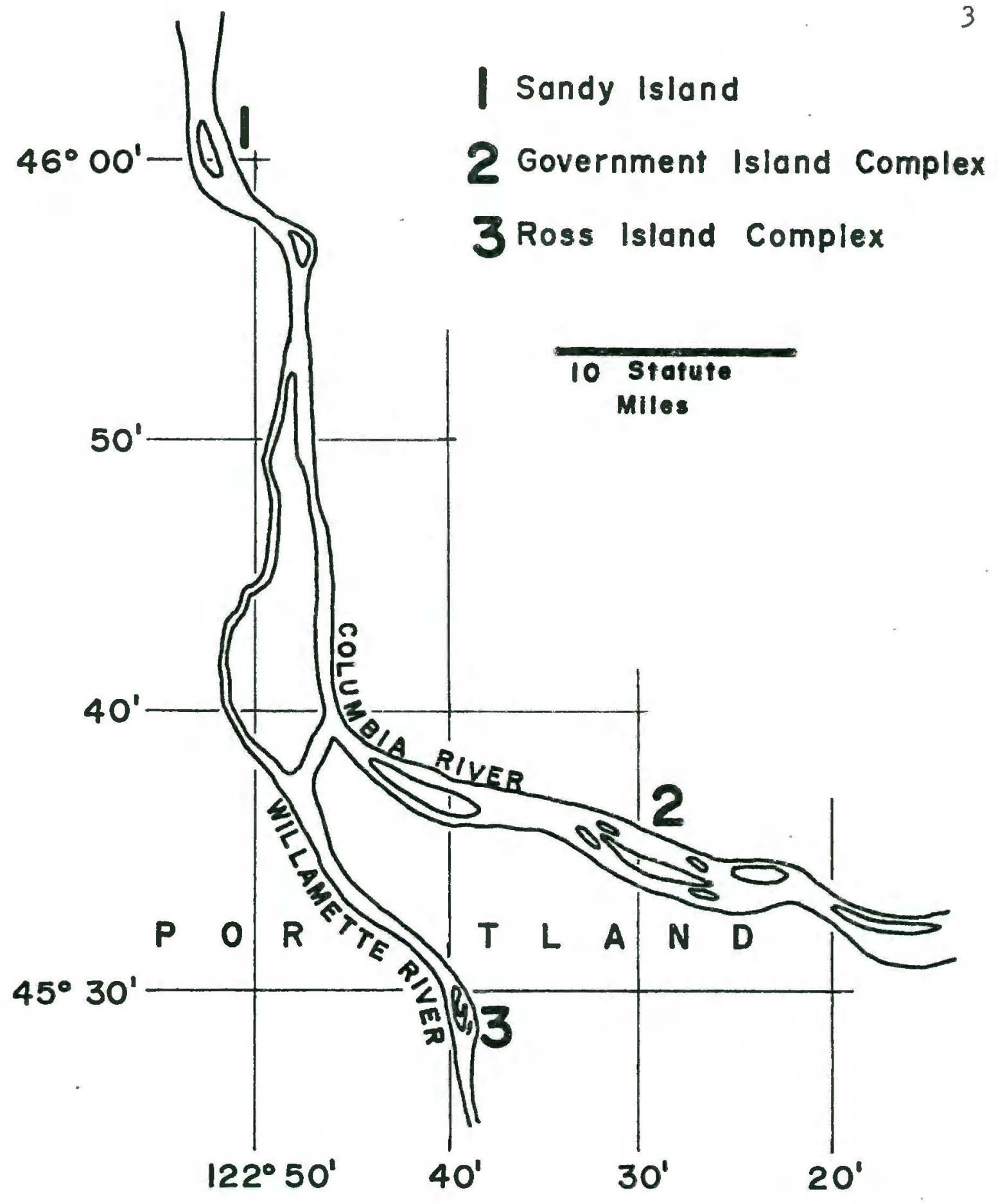

Figure 1. Location of the islands surveyed. 


\section{MATERIALS AND METHODS}

Several criteria were used for selecting the islands to be surveyed. Islands had to be large enough to support more than a few individuals, thus excluding such islands as Toe Island. Also excluded were islands such as Sauvie and Hayden because they are connected to the mainland by bridges and are large enough and commercialized to such an extent that I suspected that small mammal populations would be significantly modifjed from their undisturbed condition. The islands selected had only minimal human development. They also were selected near the city of Portland because undeveloped islands near urban centers seem most subject to change as a result of agricultural, industrial and residential development and increased recreational use. A gasoline shortage in 1974 severely limited travel and also encouraged selection of islands near the city. All islands selected for study are normally isolated by water from the mainland throughout the year. This is in contrast to others, such as Elk Island in the Willamette River, which are connected to the mainland during periods of low water but are islands at other times. The islands studied are not completely flooded during high water. 
Trapping was conducted with the objective of sampling the major habitats on each island. A variety of traps was used to increase the probability of sampling all of the species of small mammals present except bats. Museum Special Rodent Traps were used for trapping zapodids, cricetines, microtines and soricids; scissor and guillotinetype stab mole traps for talpids; Sherman traps for mustelids, zapodids, cricetids and sciurids; modified Young traps for mustelids; and pitfalls for soricids and microtines. Back-break mous = traps were used on only one occasion for cricetids, zapoajids and soricids. Observations of scats, tracks, burrows and dead animals were noted.

Museum Special and Sherman traps were set along linear transects in groups $0 \overrightarrow{\mathcal{I}}$ three, with approximately one foot between traps and approximately ten feet between groups. Modified Young traps were scattered about singly under vegetation on the islaris. Mole traps were set wherever mounds were observec. To do this, burrows were dug out until one with a conspicuous descending angle, presumably leading to the nest, was found. The trap was set at this runway and the moith was then covered with dirt. Pitfalls were set next to falien trees where runways were likely to exist. These were constructed by burying one-, two-, or three-pound coffee cans so that their open ends were flush with or slightly below the ground surface. 
All snap traps were baited with a mixture of pearutbutter and oatmeal. Pitfalls and mole traps were unbaited. A variety of bait was used in the live traps set for weasels, including feret feces, domestic rabbit kidneys and dead Perognathus. Traps were set twenty-four hours per day and checked early each morning.

Trapping was done during the months of January, May, June, August, September and November of 1974. Some additional observations of scats, tracks, and burrows were made during the spring of 1975. 
DESCRIPTION OF ISLANDS

I. GOVERNMENT ISLAND COMPLEX

Government Island $\left(45^{\circ} 34^{\prime} 33^{\prime \prime}\right.$ N. lat., 122030'30" W.

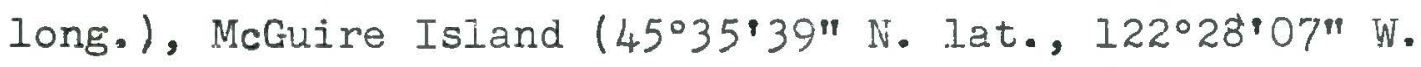

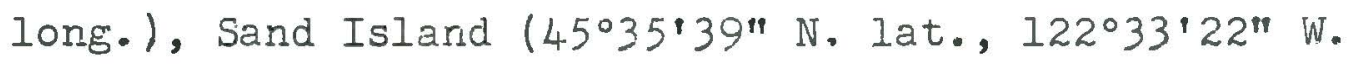
long.) and Lemon Island (45035'28" N. Iat., 122033'51" W. long.) form a cluster in the Columbia River (Figure 2). According to nautical charts (N.0.A.A., 1975) there are sand bar connections between Government and each of the other islands at mean lower low water. I have observed connections between Lemon and Government Islands every year since 1972, but never between Government and McGuire Islands, nor between Government and Sand Islands. The shortest distance across possible connections between Goverrment and Lemon Islands is approximately 180 yards, between Government and McGuire Islands is approximately 290 yards and between Goverrment anả Sand Islands is approximately 500 yards. The highest point on all islands except Sand is 30 leet above sea level. Sand Island has a peak elevation of 20 feet.

All four islands are forested predominantly with cottonwood (Populus trichocarpa). Some elderberry (Sambucus callicarpa), ash (Fraxinus latifolia), willow (Salix amygdaloides ?) and black hawthorn (Crataesus 


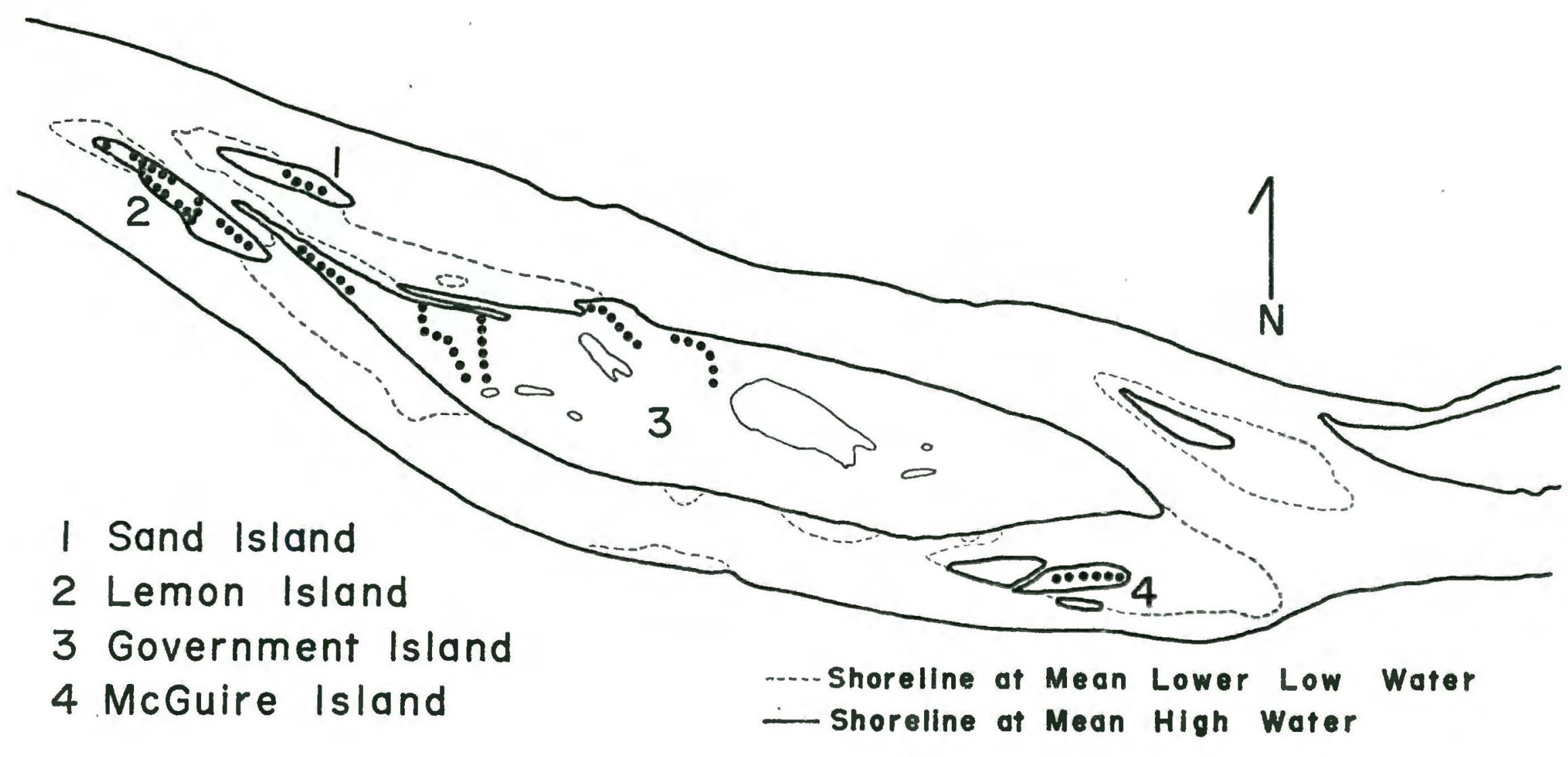

... Trap Lines

\section{STATUTE MILE}

Figure 2. Government Island complex. 
douglasii) are also found. The understory consists mainly of nettles (Urtica dioica), clumps of Rubus $\mathrm{sp}$. , some Equisetum sp., and such shrubs as snowberry (Symphoricarpos albus), serviceberry (Amelanchier sp.) and currant (Ribes sp.). Fallen trees and decaying forest litter are prevalent on the floor of wooded areas. Short grass meadows are also found on each island.

Both Government and McGuire Islands are heavily grazed by cattle. There are several cleared grassy pastures on Government. Evidence of former human occupation on these islands includes the remains of several houses and barns, old orchards and fences.

Pile dikes placed at the eastern end of Government and McGuire Islands by the U.S. Army Corps of Engineers has had the effect of causing accretion on the islands as well as between them. Government Island has received dredging spoils on the western end. Lemon Island has also received dredging spoils on the western end from both the Corps of Engineers and the Port of Portland. A wrecked fishing vessel caused the formation of Sand Island. It is currently migrating downstream at approximately 30 feet per year. It has also received some material from dredging of the river (C. Galloway, pers. conm.). Government Island is the largest island, 1802 acres. McGuire, Lemon and Sand Islands are $92,8 d$ and 35 acres, respectively. 


\section{SANDY ISLAND}

Of all the islands studied, Sandy Island (Figure 3) is the farthest removed from Port].and. Near the northern end, in the interior of the island, is a cottonwood-willow forest with little understory. Short grass covers the floor. Between this area and the sandy beaches, the floor is covered by a heavy mat of dead grasses through which living grasses penetrate. In the central part of the island is an open cottonwood-ash forest with a very sparse understory and not much grass. At the southern end is a large clearing covered with short grass.

Human activity is also evident on this island. The scuthern end has been grazed by cattle. The remains of a structure built for cattle are found here as well. There are dredging spoils at several places on the southern end and signs of the presence of large machinery. A pile dike at the southern end has caused much accretion to occur. Since the early 1900 's Sandy Island has increased its size four times (C. Galloway, pers. comm.). It is the second largest island studied, with a total of 340 acres.

\section{ROSS ISLAND COMPLEX}

Ross, East and Hardtack Islands are found within a short distance of each other in the Willamette River (Figure 4). Hardtack is now connected to the southern end of 


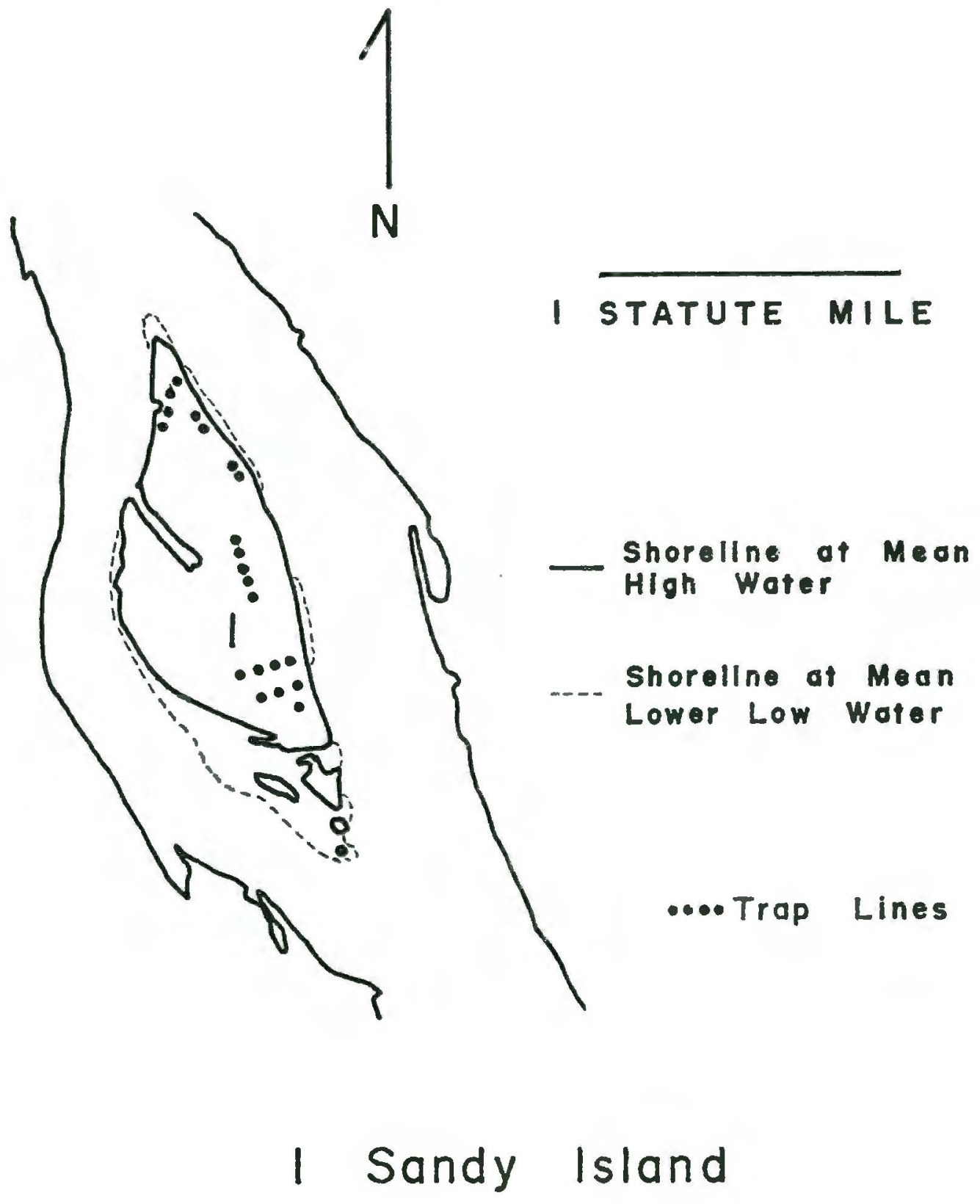

Figure 3. Sandy Island. 


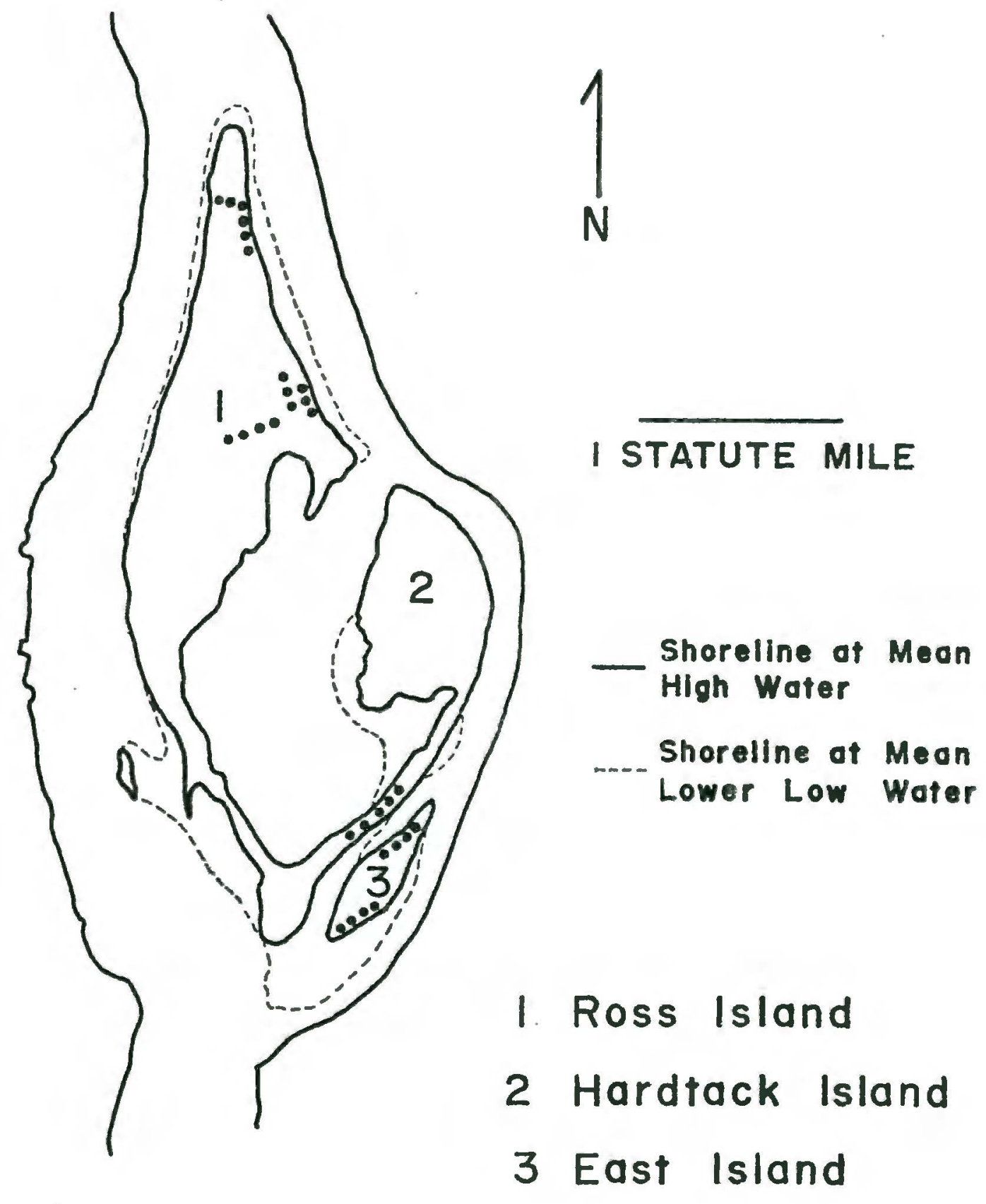


Ross Island.

All three islands are forested wi.th cottonwoods and some ash and elderberry. A grove of oaks (Quercus garriana) is located in the interior part of Ross Island at the northern end. "The understory on Ross-Hardtack consists of Rubus sp., nettles, thistles and some shrubs and grasses. On East Island, Equisetum sp. dominates the understory along with considerable stands of Rubus sp.

A conrection exists between East and Hardtack Islands during low water. Such a connection was observed during the summer of 1972. The shortest distance between these islands is approximately 70 yards.

Ross-Hardtack is the only island in this complex greatly affected by man. It is currently being dredged for gravel, resulting in removal of part of the island with consequent disturbance of the habitat and wildlife. Although Ross-Hardtack is being dredged away, it is still the largest island of this group with a total of 247 acres (U.S. Army Corps of Engineers, 1974). The area of East Island is 14 acres. 


\section{RESULTS}

A checklist of island nammals is found in Table $I$. The collection data from each island are summarized in Table II. Other cbservations are summarized in Table III except for observations nade regarding the sand bar between Government and Lemon Islands. Although no tracks of small mammals were seen on this sand bar, tracks of raccoons (Procyon lotor) and blach-tailed deer (Odocoileus hemionus, prob. columbianus) were observed. 
TABLE I

CHECKIIST OF MAMALS

\begin{tabular}{|c|c|c|c|c|c|c|c|}
\hline Species & 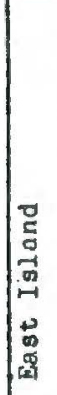 & 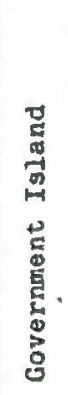 & 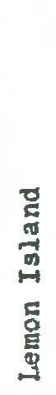 & 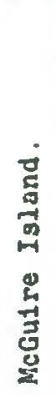 & 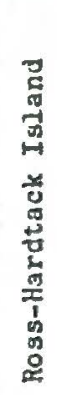 & 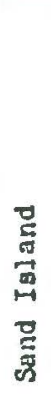 & 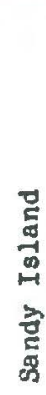 \\
\hline 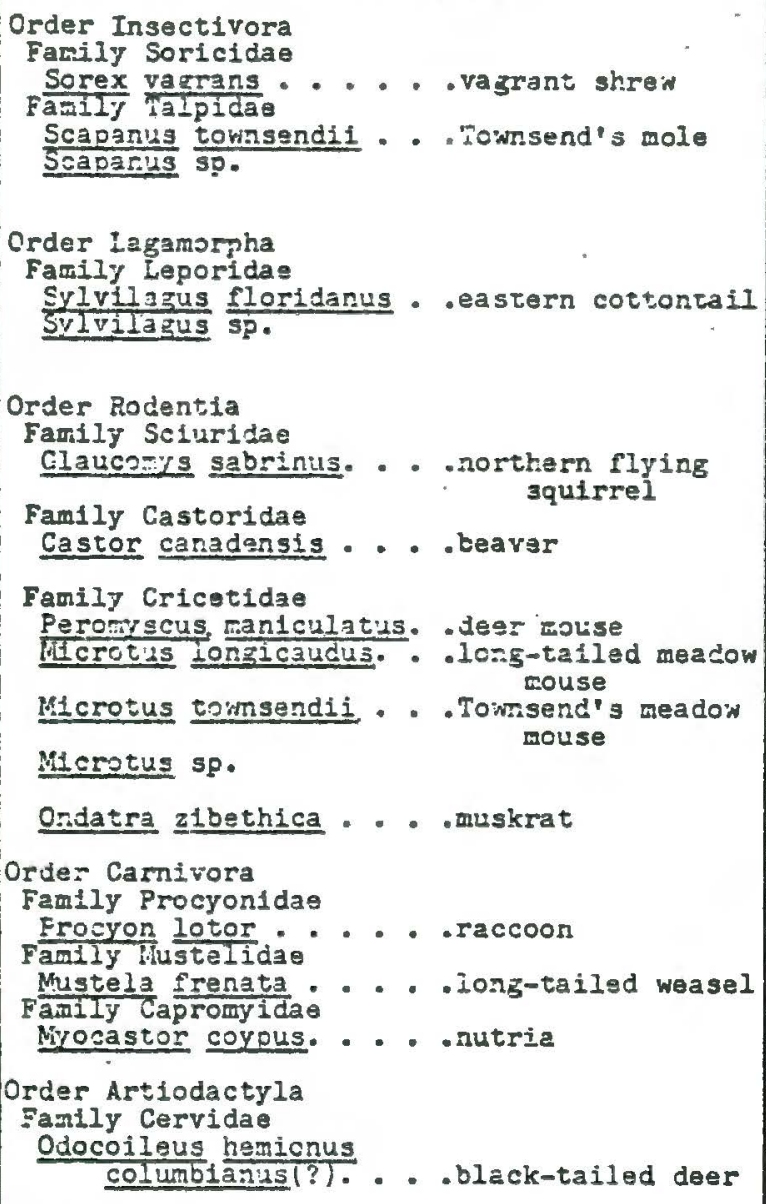 & $\Sigma$ & $\mathbf{E}$ & $\begin{array}{l}C \\
0 \\
E\end{array}$ & $\begin{array}{l}0 \\
E \\
E\end{array}$ & $\begin{array}{l}\mathrm{C} \\
\mathrm{O} \\
\mathrm{E} \\
\mathrm{C}\end{array}$ & $\stackrel{\mathrm{C}}{\mathrm{C}}$ & $\begin{array}{l}\mathrm{C} \\
\mathrm{C} \\
\mathrm{E}\end{array}$ \\
\hline
\end{tabular}

$C=$ captured

$E=$ evidence such as tracks, scats, mounds, burrows, cuttings

o - observed 
TSPLE II

COLLECTION DATA FROM ISLANDS IN THE COLUMBIA AND WILIAMETTE RIVERS

\begin{tabular}{|c|c|c|c|c|}
\hline \multirow[b]{2}{*}{ Date } & \multirow[b]{2}{*}{ Island } & \multirow[b]{2}{*}{$\begin{array}{l}\text { Trap } \\
\text { Nights }\end{array}$} & \multicolumn{2}{|c|}{ Specimens Collected } \\
\hline & & & $\begin{array}{l}\text { Nuber } \\
\text { Irapped }\end{array}$ & Species \\
\hline 25 May 74 & McGuire & 100 & $\begin{array}{l}4 \\
1 \\
1\end{array}$ & $\frac{\text { Peromyscus maniculatus }}{\frac{\text { Microtus }}{\text { longicaudus }}} \frac{\text { Sorex }}{\text { vagrans }}$ \\
\hline 18 June 74 & Lemon & 714 & $\begin{array}{l}2 \\
1 \\
4\end{array}$ & $\frac{\text { Peromvscus maniculatus }}{\frac{\text { Microtus }}{\text { sp.i }}}$ \\
\hline 9 Nov. 74 & Lemon & 50 & 0 & \\
\hline 18 June 74 & Government & 108 & $\begin{array}{l}2 \\
3\end{array}$ & $\frac{\text { Peromyscus }}{\text { Sorex }} \frac{\text { vaniculatus }}{\text { vagrans }}$ \\
\hline 9 Nov. 74 & Government & 662 & 6 & Peromyscus maniculatus \\
\hline 16 Aug. 74 & Sand & 338 & $\begin{array}{r}2 \\
14 \\
1\end{array}$ & $\begin{array}{l}\text { Microtus townsendii } \\
\text { Scaporex } \\
\text { vanus townsendii }\end{array}$ \\
\hline 4 Sep. 74 & Sandy & 522 & $\begin{array}{l}1 \\
1 \\
2 \\
4 \\
1\end{array}$ & $\begin{array}{l}\text { Microtus } \frac{\text { longicaudus }}{\text { sp. } 1} \\
\frac{\text { Microtus }}{\text { Microtus }} \\
\text { Sownsendii } \\
\text { Scapanus } \\
\text { towrans }\end{array}$ \\
\hline 4 Aug. 74 & East & 190 & 13 & Sorex vagrans \\
\hline 19 Jan. 74 & East & 25 & $\frac{1}{5}$ & $\begin{aligned} \text { Microtus sp. } 1 \\
\text { Sorex } \\
\text { vagrans }\end{aligned}$ \\
\hline $\begin{array}{l}31 \text { Aug. } 74 \\
4 \text { Aug. } 74\end{array}$ & 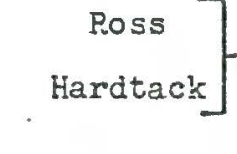 & 643 & $\begin{array}{r}14 \\
10 \\
1\end{array}$ & $\begin{array}{l}\text { Peromyscus maniculatus } \\
\text { Sorex } \\
\text { Glaucomys }\end{array}$ \\
\hline
\end{tabular}

1 Species not identified due to absence of skulls 
TABLE III

ADDITIONAL OBSERVATIONS OF MAMMALS

\begin{tabular}{|c|c|c|}
\hline Island & Species & Observations \\
\hline McGuire & $\begin{array}{l}\text { Mustela frenata } \\
\text { Microtus } \\
\text { sp. } \\
\text { Sylvilagus sp. } \\
\text { Procyon lotor } \\
\frac{\text { Odocoileus hemionus }}{\text { Castor }} \frac{\text { canadensis }}{\text { Ondatra }} \\
\text { zibethicus (?) }\end{array}$ & $\begin{array}{l}\text { sighted } \\
\text { dead remains, runs } \\
\text { grass cuttings, } \\
\text { scats } \\
\text { dead remains, scats, } \\
\text { tracks, sighted } \\
\text { tracks } \\
\text { scats, tracks } \\
\text { cuttings, trails } \\
\text { tracks }\end{array}$ \\
\hline Lemon & $\begin{array}{l}\text { Sylvilagus floridanus } \\
\text { Scapanus sp. } \\
\text { Castor canadensis } \\
\text { Procyon lotor } \\
\text { Odocoileus hemicnus }\end{array}$ & $\begin{array}{l}\text { specimen killed by } \\
\text { dog, scats } \\
\text { mounds, dead remain } \\
\text { cuttings } \\
\text { tracks } \\
\text { tracks }\end{array}$ \\
\hline Government & $\begin{array}{l}\text { Scapanus sp. } \\
\frac{\text { odocoileus }}{\text { Procyon }} \frac{\text { hemionus }}{\text { Oryctolagus }} \\
\text { Oruniculus }\end{array}$ & $\begin{array}{l}\text { mounds } \\
\text { scats } \\
\text { tracks } \\
\text { sighted }\end{array}$ \\
\hline Sand & $\begin{array}{l}\text { Scapanus sp. } \\
\text { Sylvilagus sp. } \\
\text { Castor canadensis } \\
\text { Mustela } \frac{\text { frenata }}{\text { frenata }}\end{array}$ & $\begin{array}{l}\text { mounds } \\
\text { scats } \\
\text { cuttings } \\
\text { tracks }\end{array}$ \\
\hline Sandy & Myocastor coypus & tracks \\
\hline East & $\frac{\text { Procyon lotor }}{\text { Scapanus }} \frac{\text { sp. }}{\text { Sylvilagus sp. }}$ & $\begin{array}{l}\text { tracks } \\
\text { tunnels } \\
\text { scats }\end{array}$ \\
\hline Ross & $\begin{array}{l}\text { Sylvilagus sp. } \\
\text { Scapanus sp. } \\
\text { Microtus sp. } \\
\text { Castor canadensis }\end{array}$ & $\begin{array}{l}\text { scats } \\
\text { mounds } \\
\text { runways, burrows } \\
\text { sighted, cuttings, } \\
\text { lodge }\end{array}$ \\
\hline
\end{tabular}




\section{DISCUSSION}

Only cne species of small mammal, Sorex vagrans, was found on all eight islands studied. Microtus sp. (for species, see Table I) was found on five islands and Peromyscus maniculatus on four islands. Two islands yielded Scapanus townsendii. Glaucomys sabrinus was found on only one island.

Although most species were not trapped on all islands, it seems probable that most species are found on most islands. Observations of Scapanus mounds on Lemon, Government, Ross ard East Islands indicate that moles occur there, though none were trapped. These river islands apparently produce no real problem for habitation by insectivores. Microtus was not trapped on Ross-Hardtack or Government Islands. However, burrows and runways were cbserved on Ross-Hardtack. The large size of Government, the variety of habitats found, and the trapping of Microtus on near-by islands leads me to believe that Microtus is probably found on Government Island. Peromyscus is commonly found when trapping in northwest Oregon. Their absence on Sand and Sandy Islands does not seem significant as they were trapped on other islands in the Ross and Government Island complexes.

The distribution of Glaucomys sabrinus is more 
localized than any other mammal found on the islands. Therefore, it seems unlikely that it would be found on all of the islands surveyed. The specimen collected was immature, suggesting that Ross-Hardtack may be a breeding area for Giaucomys.

On the basis of range maps (Hall and Kelson, 1959) I .. would also expect to find Spermophilus beecheyi, Eutamias townsendii, Sciurus griseus, Tamiasciurus douglasii, Thomomys bulbivorous, Neotoma cinerea, Phenacomys Iongicaudus, Clethrionomys occidentalis, Rattus norvegicus, Mus musculus and Zapus trinotatus. Absence of these species might be accounted for in one of several ways. It is reasonable to assume in a survey that every species present will not be trapped. Failure to detect the above mentioned mammals does not necessarily mean they do not inhabit the islands. It may mean they are present but were not trapped. Some species may be absent because they have not been able to make the water crossing or because, after making the crossing, they were unable to colonize and/or persist due to competition, predation, disease or lack of acceptable habitat or food.

The absence of the families Sciuridae (except Glaucomys) and Geomyidae is noteworthy. Lack of food is the most plausible explanation for the absence of sciurids. The main food staple of those sciurids found on the mainland adjacent to the islands is seeds, although some also 
consume berries, fruits, fungi and some green vegetation (Bailey, 1936). The trees on the islands (cottonwood, elderberry, ash) produce relatively small seeds and it is possible that the energy expended to collect enough food would be greater than the energy available. According to Ingies (1965) the main diet of Glaucomys is fungi in summer and lichens in winter. Glaucomys is not prinarily a seed eater (although it is known to eat nuts); it is more carnivorous than other sciurids, which may account for its presence on Ross Island.

There is no obvious reason for the absence of geomyids, particularly since moles occur there. Geomyids are able to swim (Walker, 1968) so isolation of the islands should present no real problem. A possible explanation is, again, lack of food. Geomyids feed mainly on underground parts of plants especially roots and tubers (Walker, 1968). The understory beneath the cottonwoods is frequently sparse and the ground cover is often only grass. This vegetation may not provide enough food to sustain a population of gophers.

Predation may be responsible for absence or reduced populations of some mammals. Although I did not look specifically for predators, I did observe a weasel, as well as weasel and raccoon signs. Other mammalian predators such as skunks, foxes and coyotes, as well. as predatory birds such as owls, could inhabit the islands. 
Some mammals may not be able to make the water crossing in order to reach the islands. Five alternatives are open to mammals crossing to the river islands studied: prior habitation of mainland areas that have since become islands, rafting from upstream, swimming, being transported by boats from the mainland and, in the case of the Ross Island complex, a possible connection between the islands and the mainland.

The proximity of the islands to the mainland could indicate that they once were part of the mainland. As the course of the river changed over the years, pieces of the mainland could have been cut off and isolated. Any mammals inhabiting the area would also be isolated. The species found in this survey could have been those mammals that were able to persist on newly formed islands.

The presence of large floating logs and debris (rafts), which could transport fauna and flora, is common on both rivers. During periods of trapping, checks were occasionally made for signs of mammals on floating rafts. None were seen, but this does not rule out the possibility of arrival on islands via rafts.

The islands surveyed are periodically visited by small craft (motorboats, sailboats, canoes) from the mainland. On some islands the beaches are used extensively in the summer for camping, picnicking and fishing. I observed a free roaming domestic rabbit on Government Island. It is 
conceivable that boaters do carry certain small mammals from the mainland to the islands.

Swimming ability has been established for Microtus (Fisler, 1961), Mustela (Davis, 1942), Peromyscus (Sheppe, 1965 and Orr, 1933) and Scapanus (Moore, 1939). The shortest distance between the mainland and the Government Island complex is 100 yards, between the mainland and the Ross Island complex is a distance of approximately 50 yards and between Sandy Island and the mainland is 330 yards. Peromyscus has been known to swim a distance of 765 feet whereas for Microtus and Mustela a much shorter distance of approximately 40 feet was observed. Scapanus, an excellent surface swimmer, swam for 45 minutes. Although Microtus and Percmyscus seemed to swim only when necessary to escape inclement conditions or predation, Mustela seemed to enter the water voluntarily. So for some mammals arrival on the islands could have been accomplished by swimming. Prior to the building of dams on the rivers, a connection may have been possible between East Island and the mainland. Presently, during periods of low water, rocks and sand bars are visible between the mainland and the southern tip of the island. They do not form a continuous connection but could be used as temporary stopping points for animals crossirg between the mainland and the islands. Once an arimal has arrived on one island, dispersal to nearby islands that are connected during low water would 
be possible. This does, in fact, happen in the case of larger mammals between Goverrment and Lemon Islands as evidenced by deer and raccoon tracks. It is probable that smaller mammals such as mice and shrews would also be able to traverse this connection. This is especially likely if the land exposed during low water is covered with vegetation as is the case with the land I observed in the summer of 1975 that nearly connected McGuire and Governinent Islands.

I hoped that evidence would be found to prove or disprove that current theories of island biogeography would apply to river islands as well as oceanic islands. According to MacArthur and Wilson (1967), area does not always exert a direct effect on a species' presence. Instead, area results in a large enough sample of habitats which in turn controls species occurrence. In other words, the larger the number of different habitats present on an island the larger the number of different species that could occur. However, when studying species diversity on islands the area of the islands is most often considered.

The two largest islands studied, Government and RossHardtack, offer the greatest probability for increased numbers of different habitats. Compared to these largar islands, East and Sand would probably have fewer habitats. If species diversity increases with habitat diversity, Government and Ross-Hardtack should contain more species 
than East and Sand. However, Government and.East Islands both had two species present while the remaining islands each had three species present. One explanation may be that all the islands studied have essentially the same types of habitats: cottonwood forests, a few meadows and sandy beaches. Such topographic differences as elevation could increase the divarsity of habitats. However, all the islands studied have similar topography. In terms of habitat diversity, the islands tend to be on the impoverished end of the continuum. Impoverished islands can support only a few species. Although the islands are different in size, they are similar in habitat and are impoverished. Consequently, they would support approximately the same number of species. Larger islands may support more individuals per species but not more species. MacArthur, Diamond and Karr (1972) have shown that although the total number of bird species are fewer on islands than in comparable mainland habitats, the individuals of a particular species of bird on an island can increase in density possibly due to release from competition. Once competition is lessened, island species would be able to broaden their realized niches in several ways such as expanding their habitats and widening their vertical foraging strata. A study by Manville (195I) seems to support the idea of expansion of habitat by mammals. He 
found that the entire small mammal population of a 9.5 acre forested island was two Peromyscus and twenty-five Microtus. This island lacked meadows and had only a few sparse patches of grass. Obviously, Microtus had expanded its habitat to include less appropriate forested areas. However, Diamond (1970) found that the average density of individuals in a given species remains constant or declines on an island. He also found that, despite spatial expansion of niches to include a wider range of altitudes, habitats or vertical strata by some colonizing bird species and increase in abundance by others, the total population density of birds on a species-poor island is lower than in a comparable habitat on a large, species-rich island which tends to act as a mainland.

There is no absolute answer concerning densities on islands. Whether densities on islands are the same as, greater than, or equal to the densities in comparable habitats on mainlands depends on many variables. Unfortunately, in this study data were inadequate to allow calculation of precise indices of population densities. Thus I was unable to determine if theories of island biogeography do apply to these river islands. 
SIJMMARY

A survey of small mammals was conducted on eight islands in the Columbia and Willamette Rivers. I found insectivores, microtines and cricetines to be ubiquitous. Sciurias (with the exception of Glaucomys) and geomyids were absent. I was unable to test whether theories of island biogeography apply to these river island.

Many questions remain unanswered. Among them are: the effect of siltation and spoils on island formation and composition; the effect of direct (dredging, dumping, recreation, etc.) and indirect (water quality, fallout, etc.) human impact upon island fauna; the effect of flooding on island flora and fauna; the time required for plant and animal succession on river islands; the correlations between vegetation types and density of fauna; the correlations between mainland riverbanks and islands. 
Bailey, Vernon. 1.936. The mammals and life zones of Oregon. N. Amer. Fauna. 55:1-416.

Davis, W.B. 1942. Swimning ability of two small mamals. Jour. Maminal. 23:99.

Diamond, J.M. 1970. Ecolngical consequences of island colorization by southwest Pacific birds, II. The effect of species diversity on total population density. Proc. Nat. Acad. Sci. 67(4):1715-1721.

Fisler, G.T. 1961. Behavior of salt marsh Microtus during winter high tides. Jour. Mammal. 42:37-43.

Hall, E.R., and K.R. Kelson. 1959, The mammals of North America. The Ronald Press, New York.

Ingles, L.G. 1965. Mammals of the Pacific states. Stanford Univ. Press, Stanford, Calif. 506 p.

MacArthur, R.H., J.M. Diamond, and J.R. Karr. 1972. Density compensation in island faunas. Ecology.. 53(2):330342 .

MacArthur, R.H., and E.O. Wilson. 1957. The theory of island biogeography. Princeton Univ. Press, Princeton, N.J. 203 p.

Manville, R.H. 195l. A small island community in midsummer. Ecology. 32(4):608-617.

Moore, A.W. 1939. Notes on the Townsend mole. Jour. Mammal. $20: 499$.

N.O.A.A. 1975. Columbia River, Vancouver to Bonneville. 12th. ed. National Oceanic and Atmospheric Administration. U.S. Dept. of Commerce, Washington, D.C.

Orr, R.T. 1933. Aquatic habitats of Peromyscus maniculatus. Jour. Mammal. 14:160.

Sheppe, W. 1965. Island populations and gene flow in the deer mouse, Peromyscus 1eucopus. Evolution. 19:480495. 
U.S. Army Corps of Engineers. 1974. Environmental Impact Statement on Permit applications by Ross Island Sand and Gravel Company for commercial dredging at Ross Island, Willamette River mile 15, Portland, Oregon.

Walker, E.P. 1968. Mammals of the world. 2nd. ed. The John Hopkins Press, Baltimore, Maryland. 2 vols. 